\title{
Counterhegemonic Discourse in Tengku Amir Hamzah's Poem Mabuk
}

\author{
Bima Prana Chitra ${ }^{1}$, Ikhwanuddin Nasution ${ }^{2}$, Asmyta Surbakti ${ }^{3}$, \\ Muhizar Muchtar ${ }^{4}$ \\ 1,2,3,4 Doctoral Program of Linguistics, Faculty of Cultural Sciences, \\ University of North Sumatra, Medan, Indonesia \\ e-mail: bimapranachitra@yahoo.com
}

Received: 30 September 2018

Accepted: 23 October 2018

\begin{abstract}
The research aims to implement the theory of Counterhegemonic discourse with two points of discussion: the Dutch Colonial's Social Exclusivism and Reintroducing Indonesian Cultural Identity in Mabuk, a lyric poem written by Tengku Amir Hamzah during the Dutch colonialization of Indonesia (Dutch East Indies). The poem consists of both traditional Malay rhyming scheme and modern Indonesian language structure that embody Tengku Amir Hamzah's emotional response, as well as his romantic expressions towards the state of a drunken person in metaphorical nuance with the points of inciting nationalism. The study was conducted by means of descriptive qualitative method utilizing critical discourse analysis (CDA) method with the support of deconstruction theory and phenomenological approach. The result shows that Mabuk is a Counterhegemonic poem revealing the standing of the Dutch during the colonialization era and the fading of cultural identity which is to be restored in order to get harmony in national existence.
\end{abstract}

Keywords: counterhegemonic, exclusivism, cultural identity.

\section{Introduction}

Poetry is an expression of feelings and life views of a poet observing an event of an environment with the sharpness of feelings. Through the language media modified in an artistic style, a poet becomes a mediator in expressing social problems. So, poetry and society are an inseparable unity. Everything contained in poetry is a reflection of social reality. Poetry shapes personality and becomes a good coach tool to be sensitive to the environment and all forms of problems arising in a certain community. In other words, poetry is a reflection of human life through artistic exposure, a beautiful language touching the soul.

According to Childs and Fowler (2006), poetry is a composition of expressive words in stanzas. In addition, Barfield (1997) states that poetry react on the meanings of the words it employ without any referent or veridical significances beyond and above the poets' consciousness. Therefore, the use of figurative language in poems are solely intended to evoke the readers' emotion and interpretation as to contemplate their hidden messages throughout future generations.

The presence of hidden messages in poetry are usually caused by the external codes that extend to the authors' personal and social experiences (Barthes in Endraswara, 2008), 
especially to those of political importance. Consequently, the true meaning of a poetry lies between its author's poetic authority and tendencies. In other words, a poetry can occasionally be used as means of delivering its author's political discourse.

Starting in 1964, the study of poetry and other literary works are discussed under cultural studies domain (Lubis, 2006). Cultural studies itself is an interdisciplinary approach focusing on critical interpretation of the epistemological connections between culture and politics, as well as symbols and communities in cultural artefacts to expose the underlying issues of power and dominance in a society. (Kellner, 2003) Therefore, one should perform a literary analysis by relating the work with its time of creation, author's life experiences, and social conditions.

Cultural studies tend to view poems as discursive texts; in which poets would utilize language for the purpose of delivering dialogic framework (sharing mutual facts, paradigm, experience, and importance) and hidden motives to the readers. This is in line with Hall (1997) stating that language can also be used to signify something through interpretable symbols or signs (coded meanings). For this reason, poetry is meant to represent a certain social movement.

The acts of social movement in poems can be determined from the use of critical diction. This diction, however, may relate to the use of satires and ironies to criticize certain ideologies and the flaws of a society. Damon and Livingston (2009) explained that poets tend to use political discourse as transformative social movements for the purpose of empowering the people to develop a collective state of mind. As a result, poets will eventually invoice their works against the ruling class' cultural doctrine (hegemony).

The emergence of the so-called political poetry in Indonesia can be traced back from the 1930s. During the time of the Dutch Colonialization in Indonesian (Dutch East Indies) scholars were astonished by the new literary movement of Angkatan Poedjangga Baroe (the New Poets). Angkatan Poedjangga Baroe itself was a group of Indonesian romantic poets led and established by Sutan Takdir Alisjahbana (1908 - 1994), Sanusi Pane (1905 - 1968), Armijn Pane (1908 - 1970), and Tengku Amir Hamzah (1911 -1946) in Batavia (Jakarta) in 1933. The group had published many intellectual and idealistic types of literary works in Madjalah Poedjangga Baroe (the New Poets Magazine), acting both as the leading intellectual forum of Indonesian nationalists movement (Foulcher, 1991) and the pioneer of modern Indonesian literary period (Alwi \& Sugono, 2002).

The climax of Angkatan Poedjangga Baroe literary movement can be seen from the works of Tengku Amir Hamzah, especially in Njanji Sunji (1937) and Buah Rindu (1941) lyric poem anthologies. Moreover, all of these works were written in Indonesian language and composed of several local dialects. As a result, Tengku Amir Hamzah is often considered as the biggest contributor in modern Indonesian literature development (Johns in Yusra, 1996).

Tengku Amir Hamzah's lyric poems are characterized by their beautiful rhythmic qualities. According to Teeuw (2007), a lot of his works are considered to be musical, polite, and often consist of fairy tale-like love themes. In addition, Tengku Amir Hamzah would write from a first person viewpoint $(\mathrm{I}, \mathrm{me})$ and skilfully enrich the contents with archaic and unusual loan words of that time (1930s).

In general, most of Tengku Amir Hamzah's lyric poems are inspired by llik Sundari, his Javanese lover from Surakarta (Solo), Central Java. Moreover, the poet tends to write melancholic expressions that would often reflect his happiness, sadness, longing, or anger toward her. However, there are several least known works of Tengku Amir Hamzah, such as Mabuk (Buah Rindu, 1941) that contain idealism, as well as criticism. 
Mabuk was first published in Timboel magazine's March issue of 1932 (Dini, 1981) and later in Tengku Amir Hamzah's Buah Rindu anthology (1941). It is considered as one of the poet's earliest poem during his literary career. Moreover, Mabuk portrays the state of a drunken person that might experience the feelings of loneliness, boredom, shame, confusion, and desperation.

In order to examine a poem's hidden messages, one should first correlate the work with the author's personal and communal importance (Yusra, 1996). As a poet, Tengku Amir Hamzah was born and raised by the sultanate family of Langkat, East Sumatra (North Sumatra). He was known as a prince that keenly involved in many religious, political and education activities throughout his life (Mahmud, 1994 ; Takari and Zaidan B.S., 2014).

Aside from his literary career, Tengku Amir Hamzah was once regarded as the main conceptor of Sumpah Pemuda (the Pledge of Young Indonesian Nationalists) in 1928 (Husin, 2013b). Due to this nationalist movement, he was later spied by the Dutch colonial. In 1934, the Langkat sultan ordered Tengku Amir Hamzah to marry his eldest daughter, Tengku Kamaliah in a way of avoiding further intimidation. Consequently, Tengku Amir Hamzah was forced to end his romantic relationship with Ilik Sundari (Takari et. al, 2016).

One year after the Indonesia's independence day (1946), East Sumatra was experiencing a bloody revolution led by groups of socialist activists. During that event, all monarch family members in the area, including Tengku Amir Hamzah, were slaughtered and had their assets demolished (Dini, 1981). In respect for his tremendeous amount of merits and useful contributions to the society, the government of Republic of Indonesia designated Tengku Amir Hamzah as the country's official national hero since 1975 (Husin, Ibid).

From the poet's biography, it is possible to assume that Tengku Amir Hamzah's Mabuk I is related to his political activities, as well as an intellectual movement. The lyric poem was written in order that it can be used as a romantic poet's discourse in criticizing the Dutch colonial doctrine. Thus, Mabuk contains Counterhegemonic efforts leading to emancipation practices.

The poem Mabuk is analyzed by means of Counterhegemonic approach supported by deconstructive theory having two points of discussion: the Dutch Colonial's exclusivism and Reintroducing Indonesian Cultural Identity.

\section{Literature Review}

Counterhegemonic discourse as the basic concept of the research is a kind of written or oral communication intentionally made to question and reject the misleading dominant ideology. The discourse implements introspective values in a smooth and covert manner as means of raising social awareness toward the ruling class doctrines and misconceptions. Thus, Counterhegemonic discourse seeks to educate and emancipate the oppressed society.

Counterhegemonic discourse is a critical discourse first termed by Antonio Gramsci (1891 - 1937) that challenge dominant assumptions, beliefs and established patterns of behaviour. Its construction employs the intellectual role and organic act of the author in transforming and rearticulating hegemony as to represent the interests of subaltern groups (Gramsci in Bizzini, 2008).

The realization of counterhegemonic discourse is often found in literary works. Generally, literature will try to expose the hegemonic practice records of a particular sociocultural group (Sunardi, Nurulhadi, Sungkar in Asmara and Kusumaningrum, 2018). In addition, romantic poets tend to expose counterhegemony in many lyric poems. 
Lyric poem is popularized by the European poets during the romantic period (1798 1852). This type of poem is usually short in length, spoken in first person, has beautiful rhymes, and represent its author's personal emotions or feelings. However, the subjective identity and aesthetic properties themselves may often serve as a social critique (Gui, 2007).

The introduction of lyric poem in Indonesia was done in 1933 by a group of romantic poets known as Angkatan Poedjangga Baroe (The New Poets). The group furthermore had successfully managed to spread idealism, as well as critical thinking to the society through the publication of literary works, essays and polemics of Madjalah Poedjangga Baroe (The New Poets Magazine). The success of Angkatan Poedjangga Baroe was primarily caused by Tengku Amir Hamzah's influential works; of which manage to assert the elements of local traditions, religion, nationalism and the public use of Indonesian language (Takari et. al, 2016).

\section{Research Method}

The research was conducted by means of descriptive qualitative method having a focus on social phenomena. Qualitative research is a form of social inquiry that focuses on the way people interpret and make sense of their experiences and the world in which they live. A number of different approaches exist within the wider framework of this type of research, but most of these have the same aim: to understand the social reality of individuals, groups and cultures. (Holloway: 1997) The data of this study belonged to the non-manipulated variables as they were not the result of experiment; these are called the qualitative data. Therefore, the data were analyzed with qualitative descriptive approach. The whole text scripts of the poem were used as the main sources of data supported by relevant references.

For validity, the steps taken were closely allied with interviews, survey design techniques and individual case studies, as a way to reinforce and evaluate findings over a broader scale. Having got the data collection procedures, the next step to be taken was data analysis procedures, which surely supported the whole research. Qualitative data are considered to be the rough materials the researcher collects from the world studied; the particulars forming the basis of analysis. Thus, Data collection as well as data analysis procedures was organized in line with the systematic procedures of qualitative research

\section{Discussion}

The poem consists of seven quatrains; the first three quatrains are rhymed in a-a-a-a (in the first, second, and fourth quatrains); the other three rhymed as $a-b-a-b$ rhymes (in the third, sixth, and seventh quatrains); and one quatrain with a-a-b-a rhyme (in the fifth quatrain).

The composition of the poem is inherent to the intellectual and organic role of Tengku Amir Hamzah. It clearly reflects Tengku Amir Hamzah's life experiences and careers, especially in the fields of literature, education, and politics. Moreover, the poem has represented the poet's voice in restoring the Indonesian cultural identity through the actual realization of Sumpah Pemuda (the Pledge of Young Indonesian Nationalists): to avow to one homeland (Indonesia) ; to live as one nation (Indonesian); and to speak in one language (Indonesian language).

Mabuk is intentionally written as a counterhegemonic discourse towards the fascist activities in pre-independent Indonesia (1930's). The poem reveals the expressions of boredom, confusion, shame, loneliness, and desperation, and the imagery of a drunken person in order to describe the moral degradation during the Dutch occupation. 
As an intellectual movement, Mabuk is expected to raise people's awareness of hegemonic tendencies by the consistent use of modern Indonesian language, especially in preserving cultural identity.

In general, conterhegemony is a dominant view of life and way of thinking, in which a concept of reality is disseminated in society both institutionally and individually or ideology, dictating all tastes, moral habits, religious and political principles, and all social relations, especially in intellectual and moral meanings.

Hegemony is a power or domination over the values of life, norms, and culture of a group of people which eventually turns into doctrine towards other community groups where the dominated group consciously have to give up. Groups dominated by other groups or rulers do not feel oppressed and feel it as the thing that should happen.

\subsection{The Dutch Collonial's Social Exclusivism}

"Dimabukkan harum pecah terberai

Diulikkan bujuk rangkai-rinangkai

Datanglah semua mengungkai simpai

Hatimu bujang sekali bisai

(Hamzah, 1941: quatrain 2)

The basic concept used by the colonizers is to persuade the colonized with tempting things so that the people will side with them. Community alignment with them is an additional force to expand their domination and power. The goal is to divide large groups into small pieces, and unite small groups to become the tools of the imperialist. The more divided the community is, the greater the power of the colonizers is. This system or politics of splitting get into all social domains. In the realm of culture, there are processes of foreign cultural infiltration to local traditions. The infiltration is carried out in a neat way, so it does not appear on the surface level until finally the people are shackled by the colonial power and over time the community becomes weaker as the people in chains could not do much.

A picture of the domination of the imperialist to dissolve the local culture rich in local wisdom can still be seen. The cultural concept of politeness and respect to the elders is getting fader, because the principle of freedom of expression in this matter is driven by concept of democracy, freeing and justifying almost all means. As a result, eastern cultures become faded and supple. At this time the existence and the situation are dying and will die slowly, neither east and nor west. Then a new culture called modern culture arises. Everything is sophisticated and global. This type of culture spreads and gets rooted into the nation as a historical link. Then children are born no longer knowing the customs of their own ethnic and they become the missing link generation with their own culture. This is the politics of splitting from the aspect of culture.

Likewise, in the political and economic spheres dominated by various divisions all is inheritance from the imperialist, skilful for the splintering politics. If formerly the splintering is tied to physical realm, now it is concerned with economics and politics in practice. The poem provides motivation for the awareness of nationalism by realizing that the potential for colonizing by means of a new model with the old method must be watched out by all the Indonesians. Forces uniting a diversity include mutual cooperation, tolerance and mutual respect collided with the emergence of private, regional or religious ego, excessive fanaticism so as to underestimate others making the union bond falter and eventually disintegrate. 
On the next two lines: datanglah semua mengungkai simpai; hatimu bujang sekali bisai; the words mengungkai simpai means to open the shackles and once the shackles open, then the authenticity of the inner beauty is seen. This refers to the awareness of loving Indonesia that must be raised so that the original form of the Indonesian nation that is fascinating can be seen clearly. Indonesian society is known as a friendly and helpful people. Many traditions illustrate this attitude but as the times go by, they begin to wear off.

Indonesia is based on Pancasila, the state principle, containing the noble values of the founders of the nation. It is the Pancasila that distinguishes the Indonesian nation from other nations. Pancasila contains noble values on divinity, unity, humanity reflecting epitome of a nation. The Indonesia also consists of various ethnicities, religions, races and many other types of diversity. This diversity becomes a significant attraction for a large nation such as Indonesia, a state of archipelago. The diverse state life of Indonesia often becomes the concern of outsiders to make a research.

By this, the national bond must grow in the souls of the youth, not only a must; the national bond should exist as a form of application of a self-defending instinct. For this reason, Hamzah, through his poem, states that there is a change in movement to restore the patriotism. Every change needs to have energy and great enthusiasm born from the souls that are always burning, a reflection of a clean and positive conscience. The point is when the sense of nationalism and critical attitude of the younger generation is getting weaker and the concern for big problems has been eroded, then the youth will be increasingly pulled aside and marginalized from the stage of the history of the nation's civilization.

\title{
4.2 Reintroducing Indonesian Cultural Identity
}

\author{
Bulan berbuni di balik awan \\ taram-temaram cendera cahaya \\ teja lari ke dalam lautan \\ tinggallah aku tiada berpelita.
}

(Hamzah, 1941: Quatrin 1)

This Stanza illustrates the collapse of the nation's cultural identity due to the influence of external culture. The first line Bulan berbuni di balik awan explicitly means that the moon is hiding behind a cloud, implicitly showing a cultural collapse and a riot of traditional conditions.

Taram-temaram cendera cahaya dan teja lari ke dalam lautan shows that slowly the identity of the nation's culture is increasingly getting unclear. Indonesia is an extraordinary country, a country rich in ethnicity, language and culture. Culture is an important element in forming the identity of a large group of people, especially a nation.

The world is entering the era of globalization where the goal of globalization is to unite the world's population into a single world society. Thus, in this era, globalization is more open among countries. The opening of the flow of communication and information supported by the advancement of communication tools are now easily available to everyone urging so many foreign cultures enter Indonesia and increasingly make the position of Indonesian culture shifted far from ideal.

The fading of the indigenous culture of the Indonesian people as a state identity is felt when Indonesian culture is contaminated with western culture, so that this country loses its direction in keeping up with the progress of the times. The fading of a small culture such as dressing certainly has a big impact on other traditions. If in the past the culture of respect is 
visible between parents and children and brother and sister, it is rarely seen among young people today. Tradition and local wisdom are slowly being abandoned because they are not cool, not sluggish and outdated, so the Indonesian youth loses their identity. This is because today's youth enter and followe the trends and lifestyles of today, attending to cultural prominence of the west.

Parents, who are once highly respected by children, nowadays become "friends" for children. The culture of caring for the environment and obeying the rules of the government in past times remain a history as nowadays youth simply live according to the wills. The fading of these traditions not only affects the morality of the children, but also affects the environment. So many polluted natures make the beauty of Indonesia diminished.

The religious values of the past are still solid, well-guarded, and obeyed. However, since the influx of western cultures into our beloved country, things begin to fade away slowly. The present generation now proudly displays all coming from western culture. Free sex, drug use and other immoral attitudes become the trademark of this era.

The above explanation does not mean that all the current aspects are destroying Indonesia's cultural order. Technological sophistication in the flow of globalization is a positive influence on the progress of the Indonesian nation. The positive influence of globalization can be seen in the political, economic, socio-cultural and educational aspects. Through the advanced the technology the governance could create an accountable, transparent and dynamic nuance. In the economic aspect, the freedom of foreign companies to invest in Indonesia, creates employment opportunities which are expected to reduce unemployment rates. In the field of social culture the society gets more disciplined, a high work ethic. In the aspect of education lots of positive impacts of human progress could be seen, as knowledge gained is not only from the school, campus, or other environment, but through advances in science and technology such as the internet and other social media, increasing the horizon of thinking. Globalization and foreign influence have become a natural force that affects all people on earth, something that is impossible to avoid. The only available choices are to deal with it carefully. Foreign influences can be likened to frightening germs, but as long as our nation has a strong immune system, the germs will not be a threatening force for the life of the nation and state.

The description of the two stanzas is a representation of the implementation of the hegemony theory supported by deconstruction theory, in which the ruling group that dominates the colonized group is depicted; while the interpretation of the stanza is carried out with the method of text destruction with the aim of arousing patriotism awareness which in turn benefits the future generations.

\section{Conclusion}

Maintaining Indonesian culture is an obligation for all Indonesian people. Globalization cannot shift the existence of Indonesian culture which can undermine Indonesian values and norms. This is the main theme in Mabuk poem illustrated in the results of the analysis. Social Exclusivism is a significant concept in the community, where the majority dominates minority groups in all aspects of social life. With this concept, an awareness of the nation and state must be enhanced by the exposure of the collapse of cultural identity and values in Indonesia. Both of these findings are the basis for the formation of a counterhegemoni which will then provide solutions to existing problems.

The concept of Gramsci's hegemony can actually be traced through the explanation of the basis of class supremacy. The supremacy of groups in society shows its existence in two 
ways, namely through domination and intellectual leadership. These two groups will continue to subdue each other. Usually one social group dominates opposition groups in various ways, including the power of weapons to paralyze them. On the one hand, social groups led by the intellectuals will try to fight the domination of the regime through the mobilization of kin groups, civilians and other community-based stakeholders. One hegemony can be destroyed and replaced by another social group that has a dominant position, resulting in a new ruling elite.

Thus the theory of counterhegemony is used to provide solutions to cultural problems that include the lifestyle of Indonesians deviated from their originality. Through the poem, Amir Hamzah wants to motivate awareness from all the Indonesians to maintain the cultural and national identity so that the Indonesian people will not be swayed by various influences from outside, especially in this era of globalization.

\section{References}

Alwi, Hasan and Sugono, Dendy. (2002). Telaah Bahasa dan Sastra. Jakarta: Pusat Bahasa. Asmara, Rangga and Kusumaningrum, Ratna (2018). Diksi-Diksi Gender dalam Sajak-Sajak Dorothea: Kontra Hegemoni Dunia Penciptaan Kaum Lelaki. Poetica: Jurnal Ilmu Sastra, Vol. VI No. 1 Juli 2018. Retrieved from https://www.researchgate.net/ publication/327533518 Pembongkaran Puitik terhadap Diksi-Diksi Gender dalam Sajak Sajak Dorothea Kontra Hegemoni Dunia Penciptaan Kaum Lelaki on October 8, 2018.

Bizzini, Silvia Caporale. (2008). Counterhegemonic cultural practices: the example of postcolonial women writers. Pittsburg University. Retrieved from https://www.researchgate.net/publication/39436745 Counterhegemonic cultural p ractices the example of postcolonial women writers on October 10, 2018.

Barfield, Owen. (1997). Poetic Diction: A Study in Meaning. Connecticut: Wesleyan.

Childs, Peter and Fowler, Roger. (2006). The Routledge Dictionary of Literary Terms. New York: Routledge.

Damon, Maria and Livingston, Ira (Ed.). 2009. Poetry and Cultural Studies, A Reader. Chicago: University of Illinois Press.

Dini, N. H. (1981). Amir Hamzah Pangeran Dari Seberang. Jakarta: Gaya Favorit Press. Endraswara, Suwardi. (2008). Metodologi Penelitian Sastra. Yogyakarta: Media Pressindo.

Foulcher, Keith. (1991). Pujangga Baru: Kesusastraan dan Nasionalisme di Indonesia 1933 1942, translated by: Sriwibawa, Sugiarta. Jakarta: Girimukti Pasaka.

Gui, Weishin. (2007). Lyric Poetry and Postcolonialism: The subject of self-forgetting. Taylor \& Francis Online. Retrieved from https://www.tandfonline.com/ doi/abs/10.1080/ 17449850701669609 on October 9, 2018.

Hall, Stuart. (1997). Representation: Cultural Representations and Signifying Practices. London: Sage.

Hamzah, Amir. (1941). Buah Rindu. Jakarta: Poedjangga Baroe.

Holloway, Immy. (1997). Basic Concepts for Qualitative Research. Oxford: Blackwell science.

Husin, Djohar Arifin. (2013). Sejarah Kesultanan Langkat. Langkat: Yayasan Langkat Bangun Sejahtera.

Husin, Djohar Arifin. (2013). Tengku Amir Hamzah Tokoh Pergerakan Nasional, Konseptor Sumpah Pemuda, Pangeran Pembela Rakyat. Langkat: Yayasan Langkat Bangun Sejahtera. 
Kellner, Douglas. (2003). Teori Sosial Radikal, translated by: Farichah, Eko \& Rindang Farichah. Yogyakarta: Syarikat Indonesia.

Lubis, Akhyar Yusuf. (2006). Dekonstruksi Epistemologi Modern: Dari Posmodernisme, Teori Kritis, Poskolonialisme, Hingga Cultural Studies. Jakarta: Pustaka Indonesia Satu.

Mahmud, Damiri. (1994). Amir Hamzah, Penyair Sepanjang Zaman (Penafsiran Lain Tentang Nyanyi Sunyi). Medan: Dewan Kesenian Sumatera Utara.

Takari, Muhammad et. al. (2016). "Tengku Amir Hamzah: Wira Dunia Melayu Bersenjatakan Pena", Makalah Seminar Tengku Amir Hamzah. Kuala Lumpur: Dewan Bahasa dan Pustaka.

Takari, Muhammad and A. Zaidan B. S. (2014). Amir Hamzah: Kajian Interdisiplin Terhadap Kehidupan, Gagasan, Perjuangan, dan Karya-Karyanya. Medan: USU Press.

Teeuw. A. (2007). Modern Indonesian Literature. Virginia: Martinus Nujhoff.

Yusra, Abrar. (1996). Amir Hamzah 1911 - 1946: Sebagai Manusia dan Penyair. Jakarta: Yayasan Dokumentasi Sastra H. B. Jassin. 